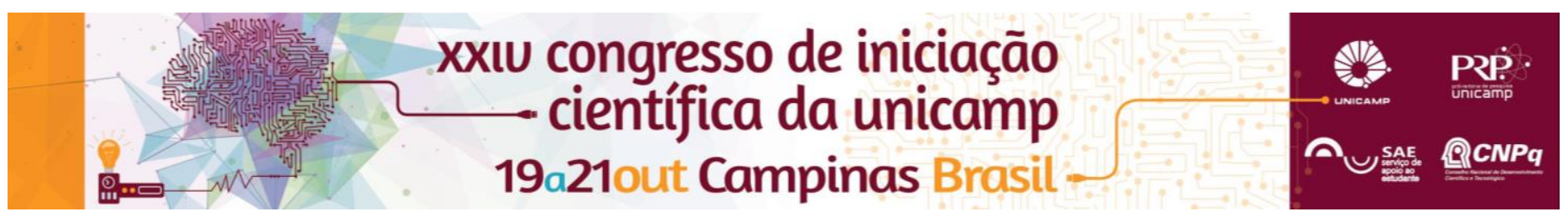

\title{
Modificação de superfície via sputtering em ligas de Titânio $\beta$ metaestáveis para aplicação como biomaterial.
}

\author{
Nayra P. Gonçalves*, Alessandra Cremasco, Raul Sebastiao Figueiredo, Rodrigo José Contieri
}

\begin{abstract}
Resumo
A pesquisa presente trata-se em modificar uma superfície da liga de titânio, contendo 35\% de Nióbio ( $\mathrm{Nb}$ ) e $7,5 \%$ de estanho (Sn) (Liga Titânio beta-metaestável), afim de melhorar a relação entre o elemento - podendo ser esta uma prótese, parafusos, entre outros - com o organismo, resultando, por exemplo, uma ação anti-bactericida e maior adesão. Esses podem ser alcançados através da aplicação de nanotubos de TiO2 desenvolvidos a partir de um substrato formado por Liga, Cu e Ti comercialmente puro.
\end{abstract}

\section{Palavras-chave:}

Titânio, Nanotubos, Sputtering.

\section{Introdução}

Apesar do uso do titânio ser extremamente vantajoso, ainda é necessário obter características desejáveis em um implante, como elementos mais biocompatíveis e uma redução do módulo de elasticidade, por exemplo, para que seja minimizado a reabsorção óssea.

A diferença entre o módulo de elasticidade entre o implante e o osso tem sido apontada como o principal fator por causar essa perda óssea, fragilizando-o. As consequências podem ser graves, como afrouxamento, falha prematura do implante ou infecções induzidas por fragmentos. Sendo assim, para minimizar tais fatores indesejáveis, ao adicionar elementos de liga como $\mathrm{Nb}$, Ta e $\mathrm{Zr}$ na liga de titânio pode-se observar uma melhora significativa, visto que esses elementos produzem óxidos insolúveis, ou seja, não provocariam reações nos tecidos, além de conseguirem reduzir o módulo de elasticidade para valores próximos ao do osso. Essa redução é algo almejado tendo em vista a importância de manter a conservação do osso.

Visando uma melhora no comportamento desses dispositivos, é necessário que haja uma melhora nas propriedades química, mecânica e biológicas. Para isso é necessário uma modificação na superfície das ligas de titânio, fazendo com que o implante de titânio se ligue biologicamente com o meio ósseo. Diante do exposto, e de parte do projeto de pesquisa apresentado, este trabalho teve como principal objetivo investigar/desenvolver a liga Ti35\% Nb-7,5\%Sn (Liga Titânio beta-metaestável) através dos processos de fundição e conformação, junto de tratamentos térmicos adequados. Ainda, de modo inovador, visou também melhorar a adesão do implante e sua ação anti-bacteriológica através da aplicação de nanotubos de $\mathrm{TiO}_{2}$ desenvolvidos a partir de um substrato formado por Liga, Cu e Ti comercialmente puro.

\section{Resultados e Discussão}

A liga de titânio do tipo $\beta$ metaestável foi obtida pelo do processo de fundição através de um forno de fusão a arco voltaico sob atmosfera controlada de argônio. $\mathrm{Na}$ sequencia, a fim de homogeneizar quimicamente e morfologicamente a microestrutura o lingote foi submetido a um tratamento térmico de 12 horas a temperatura de $1.000^{\circ} \mathrm{C}$ em um forno resistivo com o mesmo controle da atmosfera realizado anteriormente. Após o tratamento térmico o lingote foi laminado a frio com uma taxa de deformação de $4 \mathrm{~mm}$ por passe obtendo-se ao final uma redução de $90 \%$ de espessura. Para essa condição, observa-se na figura 1a uma microestrutura bastante deformada com grãos alongados na direção de laminação. Resultado de nanodureza indicam que 0 modulo de elasticidade obido foi de $65 \mathrm{GPa}$ e $245 \mathrm{HV}$ de dureza, resultados estes condizentes com o esperado para uma liga do tipo $\beta$. Para o processo de formação dos nanotubos por anodização, após a laminação as amostras forma cortadas, lixadas e polidas. Como resultado final, obteve-se nanotubos apresentados na figura $1 \mathrm{~b}$.
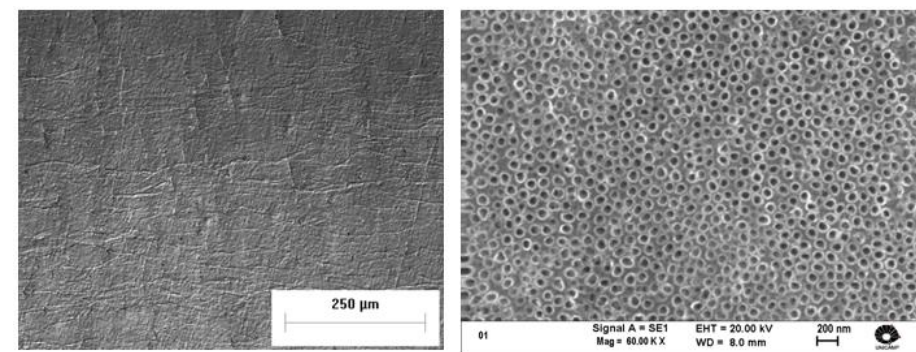

Figura 1- microestrutura (a) de grãos deformados e (b) nanotudos de $\mathrm{TiO}_{2}$

\section{Conclusões}

Até o momento conclui-se que é possível formar nanotudos a partir de superfícies depositadas vias sputtering, mantendo-se as características da liga base, como, por exemplo, o baixo módulo de elasticidade.

\section{Agradecimentos}

Gostaria de agradecer ao meu orientador Rodrigo José Contieri, pela paciência e disposição em me ajudar em todas as etapas da pesquisa e também ao CNPq, que é a minha Instituição de fomento, a qual me deu a oportunidade de realizar essa pesquisa. 